\author{
О. Є. СІЧКОРІЗ, Ю. О. РИБЕРТ, Л. Ю. МІНЬКО, О. Б. ОЛЕКСЮК, А. П. СКАЛАТ
}

\title{
РЕЗУЛЬТАТИ ПОРІВНЯЛЬНОГО ДОСЛІДЖЕННЯ ПОКАЗНИКІВ ЯКОСТІ СТОМАТОЛОГІЧНОЇ ОСВІТИ НА ПІСЛЯДИПЛОМНОМУ ЕТАПІ ПІДГОТОВКИ ЗА СПЕЦІАЛЬНІСТЮ «СТОМАТОЛОГІЯ» (ПЕРВИННА СПЕЦІАЛІЗАЦІЯ ТА ПЕРЕДАТЕСТАЦІЙНИЙ ЦИКЛ)
}

\author{
Львівський національний медичний університет імені Данила Галицького, м. Львів, Україна
}

Мета: порівняти результати кількісних та якісних показників стоматологічної освіти лікарів-інтернів та слухачів фракультету післядипломної освіти ЛНМУ імені Данила Галицького.

Матеріали і методи. У порівняльному дослідженні взяли участь 129 лікарів-інтернів циклу первинної спеціалізації за спеціальністю «Стоматологія» та 113 лікарів-слухачів передатестаційного циклу «Стоматологія» Західного регіону. Дослідження проводили у вигляді бланкового тестування 3 використанням 80 тестових питань з відкритого буклету весна 2016 «КРОК-3. Стоматологія». Статистичну обробку матеріалів проводили за допомогою комп'ютерної програми Statistica 10.0.

Результати. Найбільшу різницю між відсотками інтернів та лікарів-слухачів, які успішно склали окремі субтести, спостерігали при тестуванні на категорію субтесту П. 8 «Запальні захворювання щелепно-лицевої ділянки», при якій відсоток інтернів, які склали субтест, у 2,32 раза перевищував відповідний показник серед

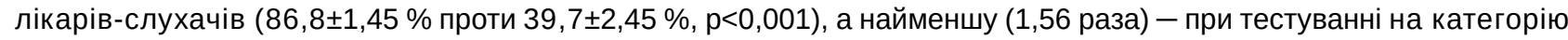
субтесту П. 13 «Ускладнення, що виникають внаслідок стоматологічних втручань» $(86,8 \pm 1,38$ \% проти 55,5 2,53 \%, p<0,001). Середній відсотковий показник тесту лікарів-слухачів із стажем роботи до 5 років становив $(50,36 \pm 1,38) \%$. Найнижчий результат був встановлений у лікарів-слухачів зі стажем роботи 5-10 років $(32,69 \pm 4,88) \%$. Щодо труднощів, які виникали у них під час проходження тесту, то $(96,5 \pm 1,74) \%$ опитаних лікарів-слухачів (109 осіб) вказали, що найважче було відрізнити відповіді на запитання за ступенем їх правильності. На думку $(84,1 \pm 3,44) \%$ опитаних (95 осіб), вони були не готові до тестування.

Висновки. Проведене порівняльне дослідження кількісних та якісних показників стоматологічної освіти на післядипломному етапі підготовки дозволило з'ясувати відсутність у більшості лікарів-стоматологів із стажем 16 років і більше навичок із складання цього іспиту. Встановлено значний регрес показників складання цього тесту в лікарів-слухачів зі стажем роботи 5 років і більше за спеціальністю «Стоматологія». Оскільки підготовка лікарів на відповідних курсах післядипломної освіти потребує певного часу, вважаємо, що протягом найближчих 5 років рівень складності іспиту для практикуючих лікарів повинен бути простішим, аніж «КРОК-3. Стоматологія» для випускників вищих навчальних медичних закладів.

КЛЮЧОВІ СЛОВА: іспит зовнішнього контролю; лікарі-слухачі; лікарі-інтерни; стоматологічна освіта.

Вимоги сьогодення налаштовують учасників навчального процесу на необхідність перегляду підходів до надання освітніх послуг. Оприлюднені результати експертних груп Світового Банку [3] та запропонованого МОЗ України для публічного обговорення Проекту професійного ліцензування лікарів [5] вказують на велику потребу інтегрувати сучасну післядипломну освіту в Україні до нових вимог. Відповідно до запропонованого МОЗ України вищезгаданого проекту, оптимальним варіантом врегулювання ситуації $є$ впровадження для практикуючих лікарів обов'язку складання іспиту («КРОК-4»), рівень складності якого буде меншим, аніж «КРОК-3», при цьому зазначається, що лікарям буде надаватися п'ятирічний перехідний період для підготовки і складання цього іспиту та три спроби його складання протягом зазначеного періоду [5].

Однак, необхідно зауважити, що складання тесту - це специфічний навик, який вимагає від лікаря належної підготовки, котра полягає не лише в з'ясуванні наявності/відсутності знань, а й у розумінні регламенту іспиту. Адже, першочергове завдання - це забезпечення рівних можливостей і прав екзаменованих [4].

Тому, для з'ясування ризиків, що можуть виникнути в процесі інтеграції іспиту, в рамках стратегії безперервного розвитку лікарів, проведено дослідження із залученням практикуючих лікарів-стоматологів Західного регіону, метою якого стало порівняти результати кількісних та якісних показників стоматологічної освіти лікарів-інтернів 
та слухачів фракультету післядипломної освіти лНМУ імені Данила Галицького.

Матеріали і методи. На кафедрі терапевтичної стоматології ФПДО ЛНМУ імені Данила Галицького проведено порівняльне дослідження кількісних та якісних показників стоматологічної освіти на післядипломному етапі підготовки лікарів. У ньому взяли участь 129 лікарів-інтернів циклу первинної спеціалізації за спеціальністю «Стоматологія» та 113 лікарів-слухачів передатестаційного циклу «Стоматологія», котрі навчалися в осінній та зимовий квартал 2018-2019 рр. Середній загальний стаж слухачів складав $(20,4 \pm 0,98)$ року, 3 яких за спеціальністю «Стоматологія» - $(19,2 \pm 1,03)$ року. Дослідження проводили у вигляді бланкового тестування [4] 3 використанням 80 тестових питань 3 відкритого буклету весна 2016 «КОК-3. Стоматологія», які були оприлюднені на офріційному сайті Центру тестування при Міністерстві охорони здоров'я України (https://www.testcentr.org.ua) [2]. Статистичну обробку матеріалів проводили за допомогою комп'ютерної програми Statistica 10.0.
Результати дослідження та їх обговорення. Оцінюючи результати тестування, варто зазначити, що включення тестових завдань 3 відкритого буклету весна 2016 «КРОК-3. Стоматологія» викликало неабияке зацікавлення зі сторони тих лікарів-слухачів, які не складали медичні ліцензійні іспити під час навчання у ВУЗі (50 осіб $(44,2 \pm 4,67)$ \% усіх лікарів-слухачів, охоплених дослідженням, стаж роботи 20 років і більше). Натомість, зі сторони лікарів-слухачів, які складали ці іспити, спостерігали певне обурення, котре проявлялося відкритим небажанням деяких слухачів проходити додаткове й необов'язкове оцінювання. Один лікар-слухач відмовився проходити тестування. Усе це зумовило підвищену складність проведення цього дослідження.

Результати проведеного тестування показали, що серед інтернів першого року навчання відсоток осіб, які успішно склали тест, був вірогідно у

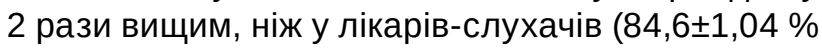
проти 42,3土1,79\%, р<0,001) (табл. 1).

Аналіз результатів субтестів проводили за 13 категоріями, перелік яких наведено у таблиці 1.

Таблиця 1. Результати кількісних та якісних показників стоматологічної освіти лікарів-інтернів та слухачів

\begin{tabular}{|c|c|c|c|}
\hline \multicolumn{2}{|r|}{ Субтести } & \multicolumn{2}{|c|}{ Відсотки осіб, які склали тест та субтести (\%) } \\
\hline Категорія & Назва & інтерни $(n=129)$ & слухачі $(\mathrm{n}=113)$ \\
\hline П. 1 & Загальні принципи & $83,1 \pm 1,48$ & $33,8 \pm 2,48^{*}$ \\
\hline П. 2 & $\begin{array}{l}\text { Первинна профілактика стоматологічних } \\
\text { захворювань }\end{array}$ & $84,8 \pm 1,63$ & $41,3 \pm 2,20 *$ \\
\hline П. 3 & Некаріозні ураження твердих тканин зубів & $84,2 \pm 1,47$ & $40,7 \pm 2,16^{*}$ \\
\hline П. 4 & Kapiec & $84,5 \pm 1,66$ & $44,4 \pm 2,95^{\star}$ \\
\hline П. 5 & Ускладнення карієсу & $85,3 \pm 1,45$ & $41,7 \pm 2,44^{*}$ \\
\hline П. 6 & Патологія пародонта & $84,1 \pm 1,53$ & $48,7 \pm 2,20^{*}$ \\
\hline П. 7 & $\begin{array}{l}\text { Патологія губ, язика, слизової оболонки } \\
\text { порожнини рота }\end{array}$ & $86,6 \pm 1,62$ & $45,6 \pm 2,53$ * \\
\hline П. 8 & Запальні захворювання щелепно-лицевої ділянки & $86,8 \pm 1,45$ & $39,7 \pm 2,45^{\star}$ \\
\hline П. 9 & $\begin{array}{l}\text { Травматичні ушкодження щелепно-лицевої } \\
\text { ділянки }\end{array}$ & $83,6 \pm 1,68$ & $36,1 \pm 2,32^{*}$ \\
\hline П. 10 & Дефекти, що потребують протезування & $82,3 \pm 1,67$ & $37,6 \pm 2,26^{\star}$ \\
\hline П. 11 & Зубощелепні аномалії та дефрормації & $84,9 \pm 1,70$ & $47,1 \pm 2,44^{*}$ \\
\hline П. 12 & Невідкладні стани & $82,7 \pm 1,59$ & $39,4 \pm 2,54^{*}$ \\
\hline П. 13 & $\begin{array}{l}\text { Ускладнення, що виникають внаслідок } \\
\text { стоматологічних втручань }\end{array}$ & $86,8 \pm 1,38$ & $55,5 \pm 2,53^{\star}$ \\
\hline & Сумарна оцінка тесту & $84,6 \pm 1,04$ & $42,3 \pm 1,79^{\star}$ \\
\hline
\end{tabular}

Примітка. Вірогідність різниці між показниками інтернів та слухачів: * $-p<0,001$.

Порівняння результатів виконання субтестів показало, що по всіх категоріях відсотки інтернів, які склали субтести, перевищували показники лікарів-слухачів (табл. 1). Найбільшу різницю між відсотками інтернів та лікарів-слухачів, які успішно склали окремі субтести, спостерігали при тестуванні на категорію субтесту П. 8 «Запальні захворювання щелепно-лицевої ділянки», при якій відсоток інтернів, які склали субтест, у 2,32 раза перевищував відповідний показник серед лі-

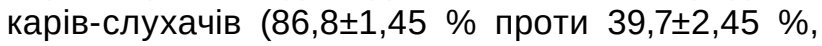
p<0,001), а найменшу (1,56 раза) - при тестуванні на категорію субтесту П. 13 «Ускладнення, що виникають внаслідок стоматологічних втручань»

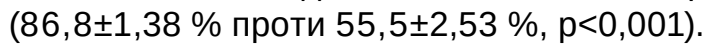

Аналіз середніх відсоткових показників тесту лікарів-слухачів із різним стажем роботи за спеціальністю (рис. 1) підтвердив припущення, що в 
лікарів-слухачів зі стажем роботи до 5 років, даний показник буде найвищим між чотирма вибірками залежно від тривалості стажу роботи (1 - до 5 років; 2 - 5-10 років; 3 - 11-15 років та 4 - 16 років і більше) та становив $(50,36 \pm 1,38) \%$. Найнижчий результат був встановлений у лікарів-слухачів зі стажем роботи 5-10 років $(32,69 \pm 4,88) \%$.

Опитування лікарів-слухачів, виявило, що усі вони мали навички складання тестів та зрозуміли порядок проведення тестування. щодо труднощів, які виникали у них під час проходження тесту, то $(96,5 \pm 1,74)$ \% опитаних лікарів-слухачів (109 осіб) вказали, що найважче було відрізнити відповіді на запитання за ступенем їх правильності. На думку $(84,1 \pm 3,44)$ \% опитаних (95 осіб), вони були не готові до тестування. Усі вони вважали, що перед тестуванням варто було б провести декілька пробних тренувань, на яких ознайомитись із тестами та обговорити методику пошуку правильної відповіді.

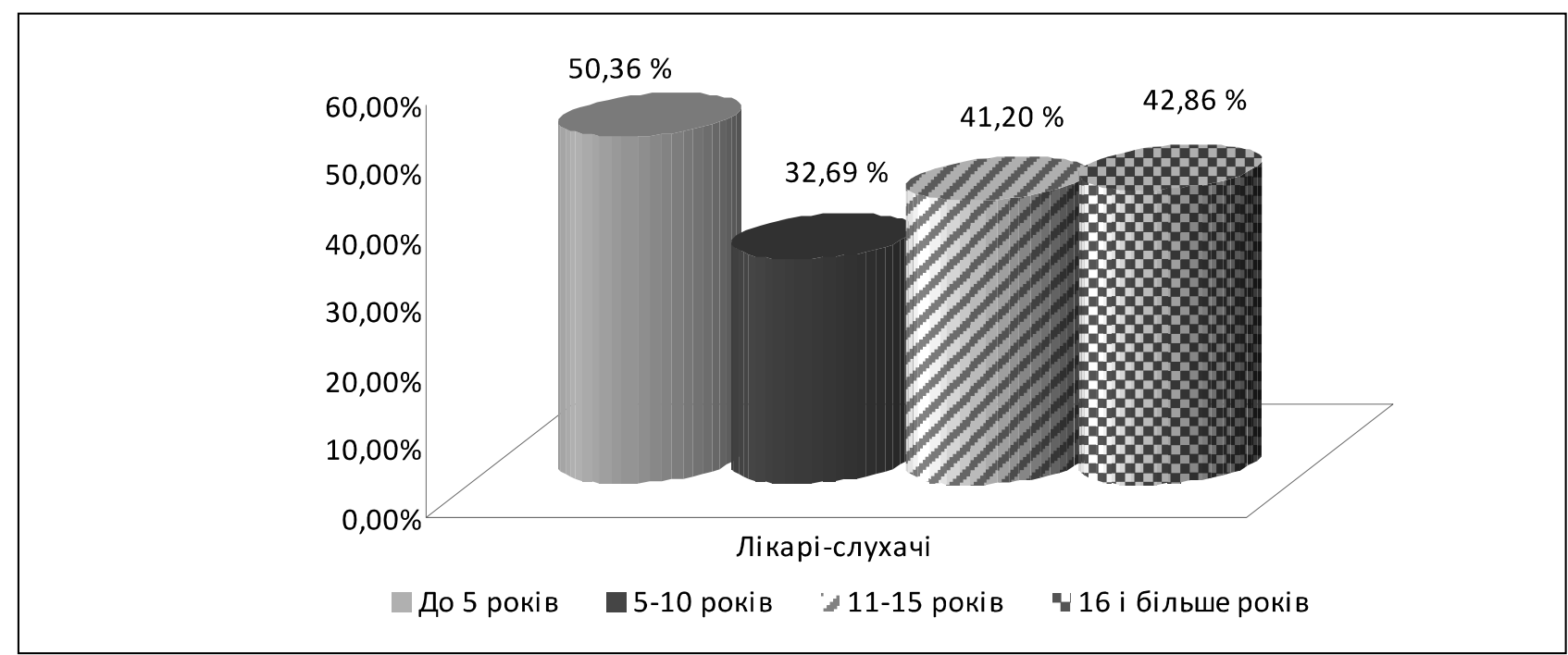

Puc. 1. Аналіз середніх відсоткових показників тесту лікарів-слухачів залежно від тривалості стажу роботи.

\section{Висновки}

Проведене порівняльне дослідження кількісних та якісних показників стоматологічної освіти на післядипломному етапі підготовки дозволило з'ясувати, що перед післядипломною освітою України під час перехідного періоду стоять нові вимоги.

Один із ключових фракторів - це відсутність у більшості лікарів-слухачів, насамперед у лікарів-стоматологів із значним професійним стажем (16 років і більше), навичок із складання іспиту «КРОК-3. Стоматологія». 3 іншого боку, встановлено значний регрес показників складання цього тесту в лікарів-слухачів зі стажем роботи 5 років і більше за спеціальністю «Стоматологія». Тому, на нашу думку, необхідно розробити навчальну програму та проводити короткотривалі курси як у дистанційній, так і в очній фрормах для здобуття даних навичок практикуючими лікарями різних вікових категорій. Це дасть можливість їм адекватно підготуватися до складання такого іспиту («КРОК-4. Стоматологія») в зручний для них спосіб і полегшить їх власну інтеграцію в зовнішній контроль 3 оцінки якості підготовки фрахівців у галузі охорони здоров'я, який пропонує МO3 України, що, в свою чергу, поліпшить якість надання стоматологічної допомоги населенню.

Беручи до уваги те, що підготовка лікарів на відповідних курсах післядипломної освіти потребує певного часу, ми вважаємо, так само як це викладено в проекті МОЗ України, що протягом найближчих 5 років рівень складності іспиту для практикуючих лікарів повинен бути простішим, аніж «КРОК-3. Стоматологія» для випускників вищих навчальних медичних закладів.

Перспективи подальших досліджень полягають у організації та проведенні таких навчальних курсів із підготовки до складання іспиту «КРОК-4. Стоматологія» на фракультетах післядипломної освіти для практикуючих лікарів дозволить навчальним закладам пристосувати свою діяльність до сучасних викликів медичного ринку праці у нашій країні.

\section{Список літератури}

1. Булах I. Є. Створюємо якісний тест : навч. посіб. / І. Є. Булах, М. Р. Мруга. - К. : Майстер-клас, $2006 .-160$ с. 2. КРОК-3. Стоматологія : відкритий буклет весна 2016 р., який оприлюднений на офріційному сайті Центру тестування при Міністерстві охорони здоров'я України [Електронний ресурс]. - Режим доступу : https://www.testcentr.org.ua. 
3. Навички для сучасної України. Огляд [Електронний ресурс] / К. Дель Карпіо, О. Купець, Н. Мюллер, А. Олефрір. - Режим доступу : https://openknowledge.worldbank.org/bitstream/handle/10986/25741/210890ovUK. pdf?sequence=5\&isAllowed $=y$.

4. Педагогічне оцінювання і тестування: правила, стандарти, відповідальність / Я. Я. Болюбаш, І. Є. Булах, М. Р. Мруга, І. В. Філончук. - К. : Майстер-клас, 2007. - 272 с.

5. Проект профресійного ліцензування лікарів [Електронний ресурс] / МОЗ України. - Режим доступу : http:// moz.gov.ua/article/public-discussions-archive/proekt-koncepcii-profesijnogo-licenzuvannja-likariv.

\section{References}

1. Bulakh, I. Ye. \& Mruha, M. R. (2006). Stvoriuiemo yakisnyi test [We create a qualitative test]. Kyiv: Maister-klas [in Ukrainian].

2. Vidkrytyi buklet vesna-2016 "KROK-3. Stomatolohiia", yaki opryliudneni na ofitsiinomu saiti Tsentru testuvannia pry Ministerstvi okhorony zdorovia Ukrainy [Open booklet Spring-2016 "KROK-3. Stomatology", which was published on the official website of the Testing Center under the Ministry of Health of Ukraine]. Retrieved from: https://www.testcentr.org. ua [in Ukrainian].

3. Del Karpio, K., Kupets, O., Miuller, N., \& Olefir, A. (2017). Navychky dlia suchasnoi Ukrainy. Ohliad [Skills for modern Ukraine. Review]. World Bank. Washington, DC. Retrieved from: https://openknowledge.worldbank.org/bitstream/ handle/10986/25741/210890ovUK.pdf?sequence=5\&isAllowed=y [in Ukrainian].

4. Boliubash, Ya.Ya., Bulakh, I.Ye., Mruha, M.R., \& Filonchuk, I.V. (2007). Pedahohichne otsiniuvannia $i$ testuvannia. Pravyla, standarty, vidpovidalnist. Naukove vydannia [Pedagogical evaluation and testing. Rules, standards, responsibility. Scientific publication]. Kyiv: Maiyster-klas [in Ukrainian].

5. MOZ Ukrainy. "Proekt profesiinoho litsenzuvannia likariv" [MHU "Professional Licensing Doctors Project"]. Retrieved from: http://moz.gov.ua/article/public-discussions-archive/proekt-koncepcii-profesijnogo-licenzuvannja-likariv [in Ukrainian].

\section{РЕЗУЛЬТАТЫ СРАВНИТЕЛЬНОГО ИССЛЕДОВАНИЯ ПОКАЗАТЕЛЕЙ КАЧЕСТВА СТОМАТОЛОГИ- ЧЕСКОГО ОБРАЗОВАНИЯ НА ПОСЛЕДИПЛОМНОМ ЭТАПЕ ПОДГОТОВКИ ЗА СПЕЦИАЛЬНОСТЬЮ «СТОМАТОЛОГИЯ» (ПЕРВИЧНАЯ СПЕЦИАЛИЗАЦИЯ И ПРЕДАТТЕСТАЦИОННЫЙ ЦИКЛ)}

О. Е. Сичкориз, Ю. А. Риберт, Л. Ю. Минько, О. Б. Олексюк, А. П. Скалат

Львовский национальный медицинский университет имени Данила Галицкого, г. Львов, Украина

Цель: сравнить результаты количественных и качественных показателей стоматологического образования врачей-интернов и слушателей факультета последипломного образования ЛНМУ имени Данила Галицкого.

Материалы и методы. В сравнительном исследовании приняли участие 129 врачей-интернов цикла первичной специализации по специальности «Стоматология» и 113 врачей-слушателей предаттестационного цикла «Стоматология» Западного региона. Исследование проводилось в виде бланкового тестирования с использованием 80 тестовых вопросов по открытому буклету весна 2016 «КРОК-3. Стоматология». Статистическая обработка материалов проводилась с помощью компьютерной программы Statistica 10.0.

Результаты. Самая большая разница между процентами интернов и врачей-слушателей, которые успешно сдали отдельные субтесты, наблюдалась при тестировании на категорию субтеста П. 8 «Воспалительные заболевания челюстно-лицевой области», при которой процент интернов, которые составили субтест, в 2,32 раза превышал соответствующий показатель среди врачей-слушателей $(86,8 \pm 1,45 \%$ против $39,7 \pm 2,45 \%, p<0,001)$, а наименьшая (1,56 раза) - при тестировании на категорию субтеста П. 13 «Осложнения, которые возникают в результате стоматологических вмешательств»

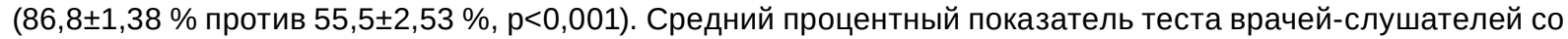
стажем работы до 5 лет составлял $(50,36 \pm 1,38) \%$. Самый низкий результат был установлен у врачей-слушателей со стажем работы 5-10 лет $(32,69 \pm 4,88) \%$. Относительно трудностей, которые возникали у них во время прохождения теста, то $(96,5 \pm 1,74) \%$ опрошенных врачей-слушателей (109 человек) указали, что труднее всего было отличить ответы на вопросы по степени их правильности. По мнению $(84,1 \pm 3,44) \%$ опрошенных (95 человек), они были не готовы к тестированию.

Выводы. Проведенное сравнительное исследование количественных и качественных показателей стоматологического образования на последипломном этапе подготовки позволило выяснить отсутствие в большинстве врачей-стоматологов со стажем 16 лет и более навыков по составлению данного экзамена. Установлено значительный регресс показателей составления данного теста у врачей-слушателей со стажем работы 5 лет и более по специальности «Стоматология». Поскольку подготовка врачей на соответствующих курсах последипломного образования требует определенного времени, считаем, что в ближайшие 5 лет уровень сложности экзамена для практикующих врачей должен быть проще, чем «КРОК-3». Стоматология» для выпускников высших учебных медицинских заведений.

КЛЮЧЕВЫЕ СЛОВА: экзамен внешнего контроля; врачи-слушатели; врачи-интерны; стоматологическое образование. 
RESULTS OF A COMPARATIVE STUDY OF DENTAL EDUCATIONAL QUALITY INDICATORS AT THE PREVIOUS STAGE OF TRAINING (PRIVACY SPECIALIZATION AND TRANSMISSIONING CYCLE) "STOMATOLOGY"

O. E. Sichkoriz, Yu. O. Rybert, L. Yu. Minko, O. B. Ololeksiuk, A. P. Skalat

Danylo Halytskyi Lviv National Medical University, Lviv, Ukraine

Purpose: to compare the results of quantitative and qualitative indicators of dental education of interns and students of the Post-graduate Education Faculty of Danylo Halytskyi Lviv National Medical University.

Materials and Methods. In a comparative study, 129 doctors-interns from the primary specialization cycle on the specialty "Stomatology" and 113 doctors-listeners of the pre-certification cycle "Stomatology" took part from the Western region. The study was carried out in the form of blank test using 80 test questions from the open booklet spring of 2016 "KROK-3. Dentistry". Statistical processing of materials was carried out using the computer program Statistica 10.0 .

Results. The greatest difference between the percentages of interns and doctors who listened successfully to individual subtasks was observed in testing for the subtest category P.8 "Inflammatory diseases of the maxillofacial area", in which the percentage of interns who made the subtest was 2.32 times higher than the corresponding the indicator among listeners $(86.8 \pm 1.45) \%$ versus $(39.7 \pm 2.45) \%, p<0.001)$, and the lowest $(1.56$ times) when tested for the subtest category P.13 "Complication that arise due to dental interventions" (86.8 \pm 1.38$) \%$ vs. $(55.5 \pm 2.53) \%, p<0.001)$. The average percentage of the test for doctors with a work experience of up to 5 years was $(50.36 \pm 1.38) \%$. The lowest result was established by doctors-listeners with a work experience of 5-10 years $(32.69 \pm 4.88) \%$. Concerning the difficulties that they encountered during the test, $(96.5 \pm 1.74) \%$ (109 persons) of the interviewed doctors-listeners indicated that the most difficult was to distinguish answers to questions on the degree of their correctness. According to $(84.1 \pm 3.44) \%$ of the respondents (95 people), they were not ready to be tested.

Conclusions. A comparative study of the quantitative and qualitative indicators of dental education at the postgraduate stage of the training made it possible to find out the absence of the majority of dental doctors with experience of 16 years or more, the skills of this exam. There is a significant regress of the indicators of the preparation of this test among doctors-students with experience in the field of dentistry 5 years or more. Since preparation of doctors for appropriate postgraduate education courses requires a certain amount of time, we believe that in the next 5 years the level of complexity of the exam for practicing doctors should be simpler than "KROK 3. Dentistry" for graduates of medical universities.

KEY WORDS: external control exam; listening physicians; intern doctors; dental education.

Рукопис надійшов до редакції 01.03.2019 р.

\section{Відомості про авторів:}

Січкоріз Орест Євгенович - кандидат медичних наук, доцент кафедри дитячих інфекційних хвороб, декан факультету післядипломної освіти Львівського національного медичного університету імені Данила Галицького; тел.: +38(032) 276-93-74; +38(050) 317-15-54.

Риберт Юрій Олексійович - доктор медичних наук, доцент кафредри терапевтичної стоматології фракультету післядипломної освіти Львівського національного медичного університету імені Данила Галицького; тел.: +38(067) 670-26-79.

Мінько Лідія Юріївна - кандидат медичних наук, доцент кафедри терапевтичної стоматології фракультету післядипломної освіти Львівського національного медичного університету імені Данила Галицького; тел.: +38(067) 721-45-65.

Олексюк Ольга Богданівна - кандидат медичних наук, асистент кафедри громадського здоров'я фракультету післядипломної освіти Львівського національного медичного університету імені Данила Галицького; тел.: +38(050) 598-83-36.

Скалат Андріана Петрівна - кандидат медичних наук, доцент кафредри терапевтичної стоматології фракультету післядипломної освіти Львівського національного медичного університету імені Данила Галицького; тел.: +38(067) 744-59-05. 